\title{
Is there any hope? The idea of strategy in business networks
}

\author{
David Ford and Stefanos Mouzas
}

\begin{abstract}
This paper explores some of the implications for the idea of business strategy of the networks of interlocking interdependencies which comprise the business landscape. The paper proposes a framework for analysing the strategic situations facing companies in business networks and for developing business strategy within them. The central message of the paper is that in the complex networks in which companies operate, business strategy cannot realistically be regarded as an individual-company activity.
\end{abstract}

The paper argues that in these circumstances, strategy is more usefully conceived of as a matrix of interdependencies that connects the structure and process of a network and that confronts the existing with the evolving.

This structure and process provide an array of evolving possibilities for the choices of any one actor and others, whether they are suppliers, customers, competitors or development partners.

The paper argues that the strategy of a single company can usefully be interpreted as part of the process of interaction through which the company and others confront aspects of the status quo with new evolving possibilities, whilst conforming to other existing patterns within the network.

Keywords: Business strategy, network, interdependencies, interaction, relationships.

Editorial Note: An earlier version of this paper was presented at the 3rd IMP Journal Seminar at Trondheim, May 2007. Thanks are due to two reviewers, and also to David Ballantyne for insightful comments.

\section{Introduction}

It is commonly asserted that behind every successful company there is a superior strategy. This conventional view of sound strategy is based on core theoretical constructs such as corporate direction, strategic leadership, competition and industry analysis (Porter, 1996; Pettigrew and Wittington, 2002; Grant, 2002). But the idea that sound strategy is the key ingredient in corporate success infers that companies are independent, proactive organizations that are complete in themselves and that are able to develop and to implement their own strategy. But empirical observation seems to show that companies are not independent. Instead they seem to be enmeshed in networks of complex interlocking interde- pendencies with each other (Axelsson, 1992; Gnyawali and Madhavan, 2001; Gadde, Huemer and Håkansson 2003; Mouzas, 2006a; Ford and Håkansson, 2006).

In this paper we explore some of the implications of these networks of interlocking interdependencies for the idea of business strategy. The paper then proposes a framework for analysing the strategic situations facing companies in business networks and for developing business strategy within them.

The central message of the paper is that in the complex networks in which companies operate, business strategy cannot realistically be regarded as an individual-company activity. We argue that in these circumstances, 
strategy is more usefully conceived of as a matrix of interdependencies that connects the structure and process of a network and that confronts the existing with the evolving. Network structure and process are the vehicles for implementing strategy as well as the source of that strategy. This structure and process provide an array of evolving possibilities for the choices of any one actor and others, whether they are suppliers, customers, competitors or development partners. For example, a producer of consumer non-durable products is embedded in a structure of inter-dependence with suppliers of raw materials and packaging, with distribution companies, food researchers, grocery retailers, consumers and others. Through a process of continuous interaction each of these actors continuously discovers some of the evolution that is likely or possible in the surrounding network. Each actor may consider what evolution it would or would not want, what that evolution would depend on and which other actors it would involve. In these circumstances the evolution of a single company's strategy within a complex network is both facilitated and constrained by the evolution of the network as a whole.

Thus, the strategy of a single company can be interpreted as part of the process of interaction through which the company and others confront aspects of the status quo with new evolving possibilities, whilst conforming to other existing patterns within the network. For example, a retailer and a manufacturer may seek to develop new products with each other. This aim may mean that the retailer is less able to work closely with other manufacturers that in turn may reduce their financial and advertising support to it and may seek developments with a competing retailer. The manufacturer's new-product cooperation with the retailer may lead it to collaborate with a willing packaging supplier. But that collaboration may conflict with the intentions of a raw material supplier on which the companies have previously depended. The raw material supplier's unhappiness may lead the manufacturer to try to develop new relationships directly with companies that had previously been suppliers to the unwilling raw-material supplier. All of the companies involved in these strategic intents and the reactions to them will be based on the actors need to access resources and skills that can only be obtained through relationships with other companies in the surrounding network. In this way the strategic intent of any one company is mediated through the network. Hence, the outcomes for any one actor are less the result of its individualistic strategy and more the result of multiple interaction and interpretation by many companies.

\section{A view of business networks}

It is important to establish initially that this paper is based on a view of business networks that has developed within the IMP Tradition ${ }^{1}$. This view can be summarised as follows:

- Structure: A business network is comprised of an evolving structure of relationships and interdependencies between actors ${ }^{2}$ that pre-exists the entry to it of any single company or other actor (Ritter, 2000; Ritter and Gemunden, 2003). This structure of relationships and interdependencies provide the dynamic context within which a company operates and which it influences. A business network has no identifiable boundary (Araujo, Dubois and Gadde, 2003). It is not limited to those other actors with which any one actor has contact or knows of or has a relationship with or appears to influence or be influenced by. A business network can have no centre, nor is it the creation of, nor can it be owned or controlled by any one actor.

- Process: The process that takes place within a business network is that of multi-lateral interaction, both conscious and unconscious between individually significant actors (Håkansson et al, 1982, Håkansson and Ford, 2002).

This IMP idea of business networks is intended to encompass the reality of multifarious but related interdependencies and interactions. These affect any single actor at a particular time, whether directly or indirectly and limit the actor's ability to comprehend or influence them.

This view of networks is rather different from that taken in much of the strategic management literature.

\footnotetext{
${ }^{1}$ See impgroup.org

${ }^{2}$ We use the term 'actor' to refer to those in the network including 'actor firms', government bodies, trade organisations, universities and developers etc. For the purposes of some analysis the relevant actors will be individuals or subgroups.
} 
That literature is often based on the idea that an individual company is able to establish its network for its purposes and which it directs and manages as part of its strategy (Gulati and Nohkia 2000, Madhavan et al, 1998, Lorenzoni and Lipparini, 1999 and Zakeer and Bell, 2005) ${ }^{3}$ The strategy literature also often restricts attention to those relationships that are defined as cooperative (Grant, 2002).

The IMP view is also different from that taken in those studies into social institutions and elsewhere that are concerned with networks that are identified or established for specific purposes by some agency. Examples of this are seen in studies of geographically circumscribed groups of actors that are considered to comprise a more-or-less self-supporting "cluster”, for innovation or development (Almeida and Kogut, 1997; Lorenzoni and Baden-Fuller, 1995; Lorenzoni and Lipparini, 1999; Malmberg and Maskell, 2002, Porter 1998) ${ }^{4}$

\section{Infinite Connectivity}

In theory there are an infinite number of actors in a network. But at least those actors are all physical in form and readily visible, even though their actual boundaries are often difficult to determine. But the structure of a network consists not so much of the visible actors themselves, but of the relationships and interdependencies between actors. These relationships and interdependencies are more or less invisible and so it is difficult to identify the structure of a network or to describe the process of myriad, simultaneous, interconnected interactions within it ${ }^{5}$. More importantly it is effectively impossible to isolate the effects of any one action, reaction or re-reaction or its significance for the structure of the network as a whole or for different actors within it.

A realistic starting point for an examination of the idea of strategy in business networks has to take into account the infinite connectivity between the elements of interaction within a network and the multiple interpretations by different actors of any interaction, of its effects and the connectivity between it and others. In this situation it would be difficult to fully analyse even a relatively simple situation between two actors, or the effects of any single action by one, or the likely response of another. Any attempt to go beyond this and to develop an overarching interpretation of what was happening in a network or a complete view of a company's position within it is likely to involve some wild imagination. Any attempt by a company to develop a strategy for the long-term in such a situation would involve some increasingly heroic assumptions about outcomes, reactions, further outcomes and arbitrary "end points." The sheer unknowability of effects and outcomes in a network means that we may even conclude that the effectiveness of strategic business decisions over time is likely to be largely a matter of luck, or simply that business is like politics and always ends in failure!

But all management involves decision-making under uncertainty and expensively educated managers are still paid to develop strategies and some of them appear to be successful - at least for a time. Entrepreneurs and new entrants do succeed in shaking up whole industries. To what extent do these things happen because of good fortune or astute analysis and are there common factors that lie behind successful strategising in business networks?

\section{A framework for analysis}

Perhaps some modest clarity in thinking about strategy in business networks could emerge from an examination of some aspects of the structure and process of business networks as we have outlined above ${ }^{6}$. This examination will allow us to conceptualise strategy as a matrix that connects the structure of the network and the process within it and which confronts the existing order with the new potentials inherent in business networks.

\section{The structure of networks}

We will first consider the two basic elements of the structure of business networks: Interdependencies and Relationships. This will then lead us to a brief examination of the idea of an over-arching "Constitution” of a particular network (or part of a whole) that frames this structure. Finally, we will examine the Position of 
a single actor or company in this structure.

\section{Interdependencies and Relationships}

The interdependencies that exist between actors are a defining feature of the structure of business networks and provide an important distinction between networks and the characteristics associated with a market. These interdependencies limit the freedom of choice of actors and their ability to change the counterparts with which they interact.

We are used to the idea that homogeneity characterises the interactions between individually insignificant actors in a market. Change in a market is likely to emanate from outside the market and impact all actors in similar ways. In contrast, the interdependencies between the individually significant actors in a network lead to heterogeneity in those interactions and in the structure across a network. Change in a network is likely to be generated within relationships and any change considered to be "external" " to the network will be mediated by relationships and so affects each company differently.

The pre-existing interdependencies in a network affect the resource investments of participants. Subsequent investments by different actors and the evolving interdependencies between them are outcomes of their interactions. Business relationships provide the arena for both parties to attempt to manage and exploit the benefits of those interdependencies. The development of relationships between companies also means that it is realistic to suggest that many resources in a business network exist in the relationships between companies. It is important to emphasise that companies in business networks either consciously or unconsciously may choose or allow themselves to become dependent on the resources of others with which they have either direct or indirect relationships. Similarly, companies in business networks seek or allow the dependence of others on themselves within those relationships.

An attempt to understand at least something of the existing structure of interdependencies and relationships in a network is an important basis for strategic thinking in business. The process of strategising in the network world can be interpreted as the attempts by companies to choose, develop, control and manage their own and others' interdependencies, the relationships in which they operate and the resource investments that arise from these.

The language of business includes many terms that are commonly used to describe some or all of the structure of their surroundings, such as supply chain, network, distribution channel, customer or supplier-portfolios. Many of these terms pose dangers for the strategist because they are often based on an egocentric view of the network, by for example inferring that it is the company's own supply chain or distribution channel and that companies in it exist for the company's own purpose.

The strategist in a business network will need to avoid the problems that inevitably arise when an ego-centric view is taken of a network. For example, most portfolio models are concerned with factors such as customer profitability and cost-to-serve or supplier capability and performance or price. For a review see Zolkieweski and Turnbull (2002).

Portfolio models may be useful to the strategist in analysing "customer" or "supplier" characteristics. But it is equally important for the strategist to examine her own position in the portfolios of others (whether that position has been planned or not) and the portfolios and wider position of third parties.

\section{Constitutions of Networks}

The term constitution of networks refers to an important and widely-observed characteristic of the structure of business. Not all of the actors in a business network will have an identifiable relationship with each other. But all will be related to each other and affected, however distantly by what happens between all others ${ }^{8}$. Some of these effects will be immediate and specific, such as the effects on its suppliers of an important customer. Other effects of relatedness will be equally important, certainly longer lasting and pervasive. These pervasive effects comprise the network constitution and consist of the rules, norms, culture and patterns of behaviour that are considered normal or acceptable in a network.

\footnotetext{
Of course there is always a problem in talking about "a" network and "the" network. If we take the view that the network of business actors is effectively without boundaries, then any particular network

8 We use the term "actor" to refer to those in the network including actors, government, trade organisations, universities and developers etc. For the purposes of some analysis, actors may include subgroups or individuals within other actors.

That we may visualise will be demarcated by our particular pre-occupations at that time and by our idiosyncratic "Network Pictures" (Ford et al 2003)
} 
Some aspects of network constitutions may have legal standing and extend across industries and countries, such as property rights, accounting standards, the requirement to exercise 'due diligence' when planning an acquisition or the rules of arbitration or company law (Loughlin, 2005, Strauss, 1999). Other aspects are specific, but also enforced by quasi-legal statute such as the codes of conduct of various professional bodies. Other aspects are based on standard terms of trade, ideas of 'acceptable' competition or the 'correct' ways to do business. Examples include standards of good faith and fair dealings, quality and industry standards, approved patterns of advertising and promotion, warranties and overt and covert collusion between companies. Many of these aspects of Constitution affect the behaviour of different actors within a actor or between actors, such as the conflict that may occur between an accountant or lawyer concerned with issues of professional rectitude(!) and a sales director motivated by what he sees as the "reality of the market" in which “everyone knows” you have to bribe.

Many aspects of a Constitution are stronger amongst longer established actors or networks. At the same time in all networks there are likely to be deviants who do not know the norms, or do not accept them and who may seek to overthrow the constitution. For early documentation of these influences see Alderson (1950, page 80) and Kriesberg (1955)

The strategist in a business network will need to examine the extent to which her interactions are influenced by her adherence to different aspects of the Constitution and the extent to which counterparts feel strongly about them. She will also have to take a considered view of when and at what cost and benefit she would consider ignoring or seeking the overthrow of the constitution.

\section{Network Position}

Network position refers to the particular place that a company occupies in a network (Johanson and Mattsson, 1992). However, that place is not simple to define. For example:
- Companies in a business network are simultaneously both customers and suppliers although, as we will discuss below, it may be difficult to assign those roles to specific counterparts in any particular interaction.

- All network positions and the interactions that surround them are unique and this heterogeneity precludes neat categorisation of actors as manufacturers or retailers etc.

- Network position is not simply a spatial construct defined by linkages with others. All actors simultaneously perform a multiplicity of roles in their different interactions and relationships with different counterparts.

- Network position is not an objective concept. Each actor in a network picture will occupy different positions in that network when seen from the perspective of different actors and depending on the focus of attention of those actors at any one time $^{9}$.

It is these different roles that together comprise an actor's network position, so that position is comprised of the relationships in which it is involved and the rights and obligations that arise from them.

Network position is a critical concept for the strategist in a business network. The strategist will be involved in assessing the current and evolving positions of counterparts as well as her own. Indeed the concept of business strategy in a network can usefully be interpreted as attempts to develop or change a company's network position relative to others in the moving world in which it is located. However, the analysis of an actor's network position will involve the strategist in reassessing the nature of an actor itself. Depending on the topic of analysis, the strategist will need to look at an actor as a corporate entity, an operating unit or an individual. More importantly, the strategist will have to view an actor in terms of its internal resources and its far more important external resources that it accesses via its relationships with others. These external resources are the outcome of its position in the network and dramatically affect its capabilities and its activities.

\footnotetext{
${ }^{9}$ We will expand on this idea below when we discuss Network Pictures.
} 


\section{The process of networks}

We will start by considering Interaction as the core of the network process. We will then move to examine some particular aspects of the nature of interaction that are important for the strategist: Problems; Time; Jointness and Relativity and Network Pictures.

\section{Interaction}

The idea that the process within a network is one of interaction immediately raises an important issue for strategising in networks: All of the interdependent companies in a network will simultaneously be trying to 'manage' the interdependencies and relationships between them and their respective positions in the network, based on their own requirements. These interdependencies and the positions of the companies at any point in time will be the result of the interaction that takes place between them rather than the aims of any one of them alone - no matter how 'powerful' it may appear.

Interaction is not restricted to conversation or negotiation. Interaction can take a physical form whenever deliveries, payments, services, learning, teaching or developments take place. Each of these will be interpreted by the counterpart and by others and contribute to their reactions.

The ubiquity of interaction and the individual significance of companies mean that any attempt to strategise in a business network will need to be expressed in interactive terms. This is likely to involve consideration of the potential effects of interaction on particular counterparts and the differential effects of similar interaction on others as well as their interpretations of these interactions and their possible reactions.

The language of strategy in an interactive world is less likely to be about the company and its market or about a generalised environment and more likely to be about interaction with specific others. Strategic thinking in an interactive world is also likely to be limited by the strategist's inability to determine the specific moves of others after a number of sequential stages or within indirect relationships. Instead, the strategist is more likely to be assessing the intent of others and searching for the direction of change in relationships across the network. Intelligence is less likely to be about macro 'networkwide' issues and more likely to be about making sense of specific others. The strongest analogy for network strategising is likely to be with multinational diplomacy rather than with battles for market share.

\section{Problems}

The heterogeneity of relationships, resources and interdependencies across a network mean that the pattern of interaction between different counterparts will also be heterogeneous. Heterogeneity is likely to exist even if the same products or services appear to be the basis on which interaction takes place. In fact the products or services that are conventionally used to define different 'markets' or to determine customer or competitor groupings are of limited value in defining a network or in strategising within it.

One way to examine the heterogeneous process of a network is to consider the interaction in it to be driven by the respective problems of all of those involved. The multiplicity of different problems of 'customers' or 'suppliers' 10 leads to the variety that exists in interaction and in the offerings of different suppliers. These interactions may involve similar products but are intended to solve different problems for the counterparts. Hence, some companies may appear to be competitors because of the similarity of their products, but may not compete at all. Others that offer quite different products may be real competitors, as they address similar problems but in different ways. Similarly, different customers that buy the same products may solve quite different problems for a particular supplier. The different problems of interacting actors will mean that the interdependencies between them can take widely different forms.

This means that strategist in a business network will need to be less concerned with considerations of conventional product characteristics and 'market' share and more concerned about the specific problems, groups of problems that she addresses for specific counterparts in particular relationships. She will also need to be

\footnotetext{
10 Collective terms such as 'customer', 'supplier', 'competitor', manufacturer, retailer etc need to be treated with great caution when discussing networks.
} 
concerned with the particular problems that are addressed for her own company in specific interactions and relationships.

\section{Time}

The idea of the process of interaction in business networks inevitably involves consideration of time. Some of the very particular aspects of time in business networks that are important for the strategist may be outlined as follows:

Episodes and Relationship Time: Perhaps the simplest but most important aspect of time in the network process is that no interaction or purchase or sale can be considered in isolation from others, whether with other actors, between actors elsewhere in the network or by the same counterparts over time. A business relationship exists when current interaction is informed by what has happened before. It is also informed by the actors' perceptions of what they would wish to follow and in turn it affects what follows.

For the business strategist, this means that her language will have to be expressed in terms of episodes, relationships, investment and return on that investment, rather than sales, profits, deals or projects.

Scale of Time: Because a network predates the entry of any particular actor, its development can be measured in the managerial equivalent of geological time - there have always been preceding events and there will always be subsequent events!

The scale of time in a business network is important for the strategist for a number of reasons: Firstly, it highlights the length of time (and the associated investment) that is often required between conventional business events, such as the time from first contact to first order and from first order to profit on relationship investment. Secondly, the scale of time means that strategic change may often take considerable time to achieve. This is because it is the relationships of an actor that enable it to act and to develop. But an actor needs to take counterparts with it in order to achieve change. These same relationships can circumscribe or slow an actor's ability to achieve change. Finally, the scale of time in a business network means that there are no end-points. Hence there is no time at which strategic change can be judged finally to have been a success or failure.

Non-Linear Time: Time in a business network is nonlinear. The process of interaction and the consequent evolution of a business relationship have no predetermined direction and certainly no predetermined speed and are subject to the aims of both of the counterparts. We will shortly examine how the managing the absolute and relative direction and speed of evolution of relationships has become an important aspect of the strategist's task.

Recursive Time: Network time is often circular. Many of the interactions between actors in business networks are repeated on a more or less regular basis, such as annual contract negotiations, quarterly reviews etc. These recursive interactions are one of the few occasions when it is possible to identify discrete episodes in interaction which can be analysed and planned for by the strategist. We will see shortly that agenda setting, for these episodes, is a key aspect in attempting to manage in individual relationships.

The Assets of Time: Many business relationships are close, complex and long term. Interactions over time may lead to relationship-specific investments by the counterparts. Interactions may develop familiarity, trust and interdependence. Over time, this familiarity, trust and interdependence can be an important asset to both companies for current and future problem solving.

However, the strategist will need to consider the length of time that is needed to develop these assets and the costs that are involved. She will also need to be aware that these investments may have little value elsewhere and hence may restrict freedom to change. Finally, she will need to be conscious that familiarity and routinisation may allow a counterpart to take an actor for granted. Hence the strategist may need to consider the importance of inter-temporal and inter-individual inconsistency in interaction to avoid being taken for granted (Ford et al, 1986) 


\section{Jointness and Relativity}

Companies may play numerous roles in different relationships as part of the process of business networks. Companies in these relationships need the resources of direct counterparts and of many others elsewhere in the network. All companies develop and exploit multiple interdependencies and address multiple problems both directly and indirectly (Gnyawali and Madhavan, 2001). These problems are their own and those of others, both that they know and don't know. Hence, all interaction in a network is "joint", even when that jointness is not apparent. All interaction in a network is relative because the same resources and interaction will have different effects in different relationships.

Identifiable products or services will appear at various points in time and space in the network process. These products and services may or may not be associated with the transfer of revenue. But they are likely to be only a partial and often deceptive indicator of the overall network process and the problems that are being addressed both immediately and across the whole network

The importance and complexity of the network process and its links to the relationships and interdependencies of companies make it a primary element in the analysis required of the strategist.

Because a network is not a market the strategist cannot expect many of the other things that are associated with a market. A network does not respond readily to any price mechanism (price for what?). A network does not tend towards equilibrium. There is no necessary reason why a network would operate for the public good at any time. Because the process of the network and its structure of interdependencies and relationships are invisible, networks may be a comfortable place in which to collude with others and an uncomfortable place to regulate.

\section{Network Pictures}

We have emphasised the complexity of the structure and process of business networks. We have suggested that no neat boundary can be drawn around a network and that it is impossible to attribute causality to out- comes of particular activities within it. Nevertheless companies in business networks do visualise the world around them; they do seek explanation and they do make predictions. They do face choices about how much of the network to examine for themselves and how much to rely on the judgement of others. We use the term Network Pictures to capture actors' individual perceptions of the world around them (Ford et al, 2003). The idea of a network picture can be useful for a strategist trying to encapsulate an actor's view of network structure, process and position . A company's or an individual's network picture may show the width or restrictions of its vision; it may view itself in the centre or on the periphery, it may be expressed as historical explanation, it may assume that the network is static, it may emphasise how it evolves, how it should evolve or how the actor plans to make it evolve.

Analysing her own network picture may help the strategist to question her assumptions about the network. The strategist may also find it valuable to examine the interactions of other actors as well as their public pronouncements and their investments as a way of inferring their network pictures that will form the basis of future interactions.

\section{The current situation}

Many of the aspects of the structure and process of business networks are increasingly apparent in the business world. Increasing costs and uncertainty in technological acquisition are leading to ever-greater interdependencies between companies. Product, process and marketing technologies are increasingly scattered among geographically and industrially dispersed companies. Even in those relationships which are not strongly technologically intensive, the considerable costs of customer acquisition, the time from first contact to first order or to profit, the need for repeat business all fuel interdependence, not only between those actors that are immediately related to each other, but along threads running across the network.

The length of time required to build relationships increasingly conflicts with the need for flexibility and change. Constitutions of networks expressed in various rules and norms are frequently challenged by network

\footnotetext{
11 The term "Network Picture" is not limited solely to a pictorial representation
} 
incomers equipped with skills acquired elsewhere. Consider, for example, the impact of the so called 'category killers' such as Toys 'R' US or C\&C in the retail world or e-business such as Amazon. At the same time conventional views of marketing and purchasing seem to be out of touch with the complex reality of business relationships in which what is being sold, to whom by whom and with whom becomes increasingly unclear. More fundamentally, the idea of success has become less clear and difficult to fix in time as well as the ingredients that are necessary to achieve it. It no longer seems to be enough to have the right product at the right price!

\section{A matrix for analysing strategy in business networks}

Figure 1 presents a matrix that may be useful to examine the range of activities for the strategist in a business network, with acknowledgements to Igor Ansoff (1957). However unlike the Ansoff matrix, the purpose of this matrix is not to show the choices for a single company in developing its individual strategy, but to show what may happen in the relationships between actors in a network.

Figure 1: a matrix for analysing strategy in business networks

\begin{tabular}{|c|c|c|}
\hline & EXISTING PROCESS & EVOLVING PROCESS \\
\hline EXISTING STRUCTURE & $\begin{array}{c}1 \\
\text { REVIEW }\end{array}$ & $\begin{array}{c}2 \\
\text { CHANGE RELATIONSHIPS }\end{array}$ \\
\hline EVOLVING STRUCTURE & $\begin{array}{c}3 \\
\text { ESTABLISH NEW } \\
\text { RELATIONSHIPS }\end{array}$ & $\begin{array}{c}\text { CHANGE NETWORK } \\
\text { POSITIONS }\end{array}$ \\
\hline
\end{tabular}

Cell 1 Review: We start by examining the continuing interaction in a single relationship between two companies. Business between the two companies in the relationship may or may not be growing. But if it is growing it is likely to be a case of more-of-thesame business rather than of addressing new types of problems for either of the companies involved. This situation is likely to apply for many but not all of the relationships of any two companies in a network at any point in time for a number of reasons: Many relationships are simply not important enough to invest the significant resources necessary to change them; or the previous investments by the companies may have achieved a steady state of interdependence; or the evolving constitutions of networks provide a comfortable life for those involved, whether they are sales people, buyers or operating units.

Relationships may exist in Cell 1 for a considerable time, often measured in years, even if both of the companies have other relationships that solve similar problems. In this case the interactions within each relationship will increase or decrease in intensity depending on the attention the companies give to specific aspects of problems, to improvements in 'efficiency' or to different relationships (Mouzas 2006b). Many of the relationships of a particular company will be in Cell 1 and sales and purchasing personnel devote much of their careers to minor fluctuations in interactions. But as we will see, they encompass only a small part of the life of the strategist.

Cell 2 Change Relationships: This cell refers to the situation when either of the companies in a relationship seeks to change some significant aspect of that relationship. The key issue for those involved in managing or developing a relationship is to decide on which aspects of the relationship it is necessary to confront and for which aspects they should conform to the existing pattern of interaction as in Cell 1 . In the recursive time in many relationships, the question facing actors is which items to put on the agenda and which to leave alone at a particular time such as at a monthly meeting. For example, in the relationship between a manufacturer and a retailer the retailer may choose to raise the important issue of 'own-brand' supplies from the manufacturer whilst accepting the current discount structure for supplies of the manufacturer's own brands. In contrast, the manufacturer may wish to confront that discount structure, but wish to avoid any involvement in own-brand supplies. This choice of issues can be an important element in demonstrating more or less commitment to a relationship and communicating a willingness to reduce or increase interdependence.

These choices in Cell 2 will broaden or narrow the options for future development for the strategist. They will need to be taken after some form of relationship assessment or audit on the specific relationship and others. 
These assessments will have to involve considerations of potential, cost, portfolio and network position, time and the view of the relationship held by the counterpart. Similarly, the strategist will frequently have to consider her response when a counterpart chooses to confront a particular aspect of their relationship.

Significant moves by any actor in Cell 2 can have wider effects. They may introduce enhanced ways of working that may then be applied in other relationships to the benefit of other actors; they may establish norms of conduct that will affect others' behaviour elsewhere in the network; they may send a message to the actor's other counterparts that it seeks to change its network position (Cell 4). Hence Cell 2 represents an unstable situation in the network.

Cell 3 Establish New Relationships: This cell illustrates a common phenomenon in business networks. This is when either of the companies in a particular relationship seeks to develop new relationships. This phenomenon is seen when sales people seek to develop new customers for their offerings or buyers seek a wider range of comparable suppliers. It is likely that any newly developed relationships will be similar to both companies' existing relationships, in terms of the levels of interdependence and the problems that are addressed. This limitation may be because companies' skills only equip them for operating in relationships that have particular characteristics, or because the companies are unable or unwilling to consider what different types of relationships are appropriate for them ${ }^{12}$.

The strategist may wish to develop new and different relationships but find that either these are simply unavailable to them or that the ones that they are able to develop are similar to the ones that they already have got (Håkansson and Ford 2002). Moves in Cell 3 raise further important issues for the strategist: These moves may require a company to develop its skills in relationship management and to acquire and allocate new resources. This will involve the strategist in important evaluations of which individual or types of relationships to develop within resource constraints. More importantly moves in Cell 3 by either counterpart to develop more or fewer similar relationships will in the short or long term affect a company's relationships with existing counterparts. We will see shortly that if these moves by either actor are on a wide scale then this can lead to an unplanned change in network position for both companies in the original relationship (Cell 4). Hence Cell 3 in the matrix also represents an unstable situation.

Cell 4 Change Network Positions: This cell refers to the situation where there is a change in the network position of interacting companies brought about by changes in the problems addressed or patterns of interaction in the existing relationships of companies and/or the addition of new relationships. As we have seen, these changes can emerge unconsciously from interaction in Cells 2 or 3 . But Cell 4 can also refer to conscious attempts to change network position by developing new or dropping existing relationships or changing patterns of interaction or interdependencies in existing ones. Common examples of Cell 4 are seen in disintermediation, where actors attempt to interact directly with those with which they have previously had only an indirect relationship and in re-intermediation, where actors attempt to establish a new position between actors that have previously interacted directly with each other ${ }^{13}$. Network positions are relative and a change in the position of any one actor inevitably affects others and the structure of the network as a whole. Any benefits achieved for some actors from changes in network pictures will have associated costs for some or all. Cell 4 also includes the changes that are attempted by actors in relationships in which they are not directly involved elsewhere in the network. Attempts at making these changes become increasingly important as companies come to depend on the activities and relationships of multiple actors that are remote from them. Finally, Cell 4 also refers to change that is likely to take considerable time and may conflict with the existing constitution of the network. For these reasons, Cell 4 is often occupied by relationships involving actors that are not subject to the existing constitution, or are 'outside' the existing network, because they have not yet developed relationships with incumbents.

Cell 4 has important implications for the network strategist. It highlights the importance for her of looking

\footnotetext{
12 An interesting example of these restrictions has been seen in the unwillingness or difficulties experienced by some companies in moving from adversarial to more open and cooperative relationships with their suppliers.

13 An interesting example of re-intermediation is provided by the multinational Li and Fung. Li and Fung has successfully developed relationships with major customers and their existing or potential suppliers to improve access for each to innovative or low-cost offerings or to new customers, without multiplying the need for difficult-to-manage relationships.
} 
outside her 'normal' operations and plans in Cells 1-3. She must appreciate how and when her overall network position may be changed by the intervention of others. Cell 4 also highlights the importance for the strategist of developing a conscious view of her network position as something that is temporary rather than permanent. Network positions continuously evolve and the strategist must be proactive in examining the potential moves of others and developing her own.

\section{Structure, process and the matrix}

Interaction will be taking place in all four Cells of the matrix simultaneously in any business network. Any one company in the network and some of its counterparts will be involved in relationships that are relatively stable (Cell 1); all will be involved in confronting various aspects of some of their relationships (Cell 2); all will be involved in adding similar relationships to their existing ones and deleting others - and being deleted by others! (Cell 3). The positions of all companies in the network will be evolving more or less rapidly at a particular time (Cell 4). This evolution will arise through their own moves and those of others, whether or not they interact with them directly.

Both of the companies in any relationship are simultaneously involved in the interaction between them - by definition. Both take a view of the interaction and will seek to change some aspects of it. Both companies are simultaneously interacting in other relationships so no one relationship can be analysed in isolation from others. Both companies will have a picture of the network and their position in it and will seek to stabilise or to change that position.

Some relationships will exhibit remarkable stability. Some will change slowly, others quickly. Some change will be peaceful and some will be violent. Each company will have some relationships that are entirely different from all its others. It will have others that are being replicated more or less by itself or its counterparts. At the same time that some companies are seeking to maintain the stability of their network position, others will be seeking to change it for them as well as to change their own.
This heterogeneity in a network is one reason why a strategist can never characterise a whole network as stable or unstable.

All networks will demonstrate stability and instability simultaneously. The network pictures of some companies may only show stability and these companies will use that stable picture as the basis for their interactions. Others will see actual or potential change and act on the basis of their pictures. No company will have a 'complete' picture of the networks. Each will only recognise some of the world around them and so there will always be potentially important actors that are 'outside' the network seen by the actors within it.

Strategy in a business network is a multifaceted activity. Much of it surrounds existing relationships that are any company's prime assets and which are the result of previous investments, interdependencies and interactions. Both companies in these relationships will have a conscious or unconscious view of them. The evolving strategic outcome within these relationships is a function of these separate views, of the interaction that takes place, their respective investments in it and of the wider picture that the companies have of the structure of the network. It is important for the strategist to develop a conscious approach to each of her relationships or groups of similar relationships in Cell 1 , based on an audit or other systematic assessment. But a strategic approach to business networks involves conscious attempts to relate existing relationships in Cell 1 to evolution in Cell 3 with more relationships and Cell 2 within existing relationships and conscious repositioning in Cell 4.

The maintenance of existing relationships in Cell 1 involves costs to both of the parties. Changes in existing relationships in Cell 2 and new or different relationships in Cell 3 affect the companies that are directly involved and others elsewhere in the network. Changes in the Network Position of any one company in Cell 4 will inevitably involve changes for others. All changes in the network will involve additional investments and costs for the companies directly involved and for others. All changes raised by one company will require the support or at least the acquiescence of others. The strategic 
outcomes of any change in the structure and/or process of a network can only be explained at the level of the network. Strategic outcomes for any one company will occur within the consequent and reverberating process of interaction across the network. Strategy for an individual company in a business network consists of assessment of the options open to it within its network position. It consists of the company's own attempts to confront issues within particular relationships whilst conforming to others. It also consists of responding to the confrontations of others within its relationships and elsewhere. Strategy for an individual company involves choices in options and resource commitment. But the interactive nature of strategy in business networks means that strategy is negotiated rather than produced. An effective organization is one that is able to create accounts of itself and of its activities that relevant constituencies find acceptable and that is able to work with these constituents to create new sources of value (Gaertner and Ramnarayan 1983, Moran and Ghoshal1999) ${ }^{14}$.

\section{Leading and Following}

The business interaction that we have described in the Matrix in Figure 1 and the approaches to management in each of the Cells does not simply consist of a series of unilateral actions by the actors that are involved in relationships. Because interaction is the network process between at least two actors, there are important choices that need to be made by the strategist about her conduct in that interaction ${ }^{15}$.

Suppose that an actor is seeking to change an aspect of a relationship at a business meeting [Cell 2 of the matrix]. The actor can ask for an item to be placed on the agenda for discussion and decision at that meeting. Once an item has been placed on the agenda, the critical issue is whose argument about the issue will be accepted after the subsequent discussion ${ }^{16}$.

Perhaps most obviously, the asymmetries in the interdependencies between the two companies will affect the direction to be followed for the issue that has been raised - on the basis of who needs who the most. But the interdependencies between two companies in a rela- tionship are not just based on their respective resources and dependencies. Their different levels of expertise, their network positions and understanding or picture of the network are also important. Each company faces choices if and when to follow the leadership of a counterpart in a particular situation and when to lead the counterpart in its chosen direction, no matter which of them may have raised the issue.

Common examples of leading and following are seen in the interaction that takes place between companies on the issue of technological development. All companies face limits to the technological resources they can acquire and maintain and hence they frequently have to follow the expertise and leadership of counterparts. These limits may mean that companies may be completely dependent on the technological leadership of their suppliers in some areas, whilst retaining sufficient knowledge to be a 'competent customer' in others and directing the technologies of their suppliers elsewhere. Similarly, examples of leading and following are often based on one of the knowledge of other companies elsewhere in the network, such as their customers or suppliers or the strength of one of the companies' standing or position in the network and its ability to affect the constitution of the network.

Control: Companies frequently seek to control the world around them, whether this control is expressed in terms of leading their relationships, optimising their supply-chain, building their joint ventures, managing their distribution channel or even acting as the hub of their network. But the pattern of interdependencies in a network, the distribution of resources, the limits to knowledge and the reality of interaction often make these aims unrealistic.

The more that a company succeeds in leading or controlling many of its relationships then more it is dependent on its own understanding and opinion and it had better be right! Unfortunately, few companies possess universal wisdom. The more that a company exercises control over a network, the more that the evolution of that network depends on the ideas of that single actor and the less scope there is or innovation that is based on the diverse resources of others. Complete control

\footnotetext{
${ }^{14}$ Moran and Ghoshal (1999) describe the process of economic development as the interplay between "networks" and firms. They maintain that historically, firm-level theories focused on issues of competitive advantage through value appropriation rather than on issues of creating new sources of value. The historical propensity may be attributed to the observation that purposive business action is far more applicable to operational efficiency gains than to the effectiveness in creating new sources of value. The implication of Moran and Ghoshal's argument is that if an business action is far more applicable to operational efficiency gains than to the effectiveness in creating new sources of value. The implication of Moran and Ghoshal's argument is that if
organization not adequately enable new possibilities, then the organization is likely to witness its own decline. Decline will come if someone else is better structured to embrace the 
by one actor would be likely to ossify the network (Håkansson and Ford, 2002).

\section{Conclusion}

The idea of strategy in business networks is built on the primacy of relationships as corporate assets. Strategy in business networks requires clarity in analysing the current situation of relationships in Cell 1. It involves conscious attempts to develop those relationships, over time and anticipation of and reaction to the aims of others and in Cell 2. It involves realism in multiplying relationships and coping with multiplication by others in Cell 3 and understanding of the resource choices that this involves.

Strategic thinking in business networks has to be based on analysis of the strategist's own picture of the network and those of others and clarity in views of network positions and the issues involved in changing and developing them. Strategy in networks is a small numbers game. It involves working with, against, through and in-spite of others. It acknowledges that most of the resources and activities on which a company depends are outside of the company and outside its control. It also acknowledges that the direction of the strategist's own company is the outcome of multiple factors and multiple interactions in Cell 4.

The idea of strategy in business networks that we have presented envisages a modest strategist, aware of dependence as well as strengths and conscious of her own smallness in the network landscape. The modest strategist is aware of the limits to her vision and wisdom, the need to follow as well as lead, to work collectively as well as individually. She is used to coping with situations as well as directing them. She is conscious of history and the complexity of time, aware of the limits to change-

But she retains at least some small hope of success-!

\section{References}

Alderson, W. (1950) Survival and Adjustment in Organized Behavior Systems, in R Cox and W Alderson (eds.) Theory in Marketing, Homewood Illinois, Richard D Irwin.
Almeida, P. and Kogut, B. (1997), 'The Exploration of Technological Diversity and Geographic Localization of Innovation', Small Business Economics. Vol. 9, No 1. pp. 21-31.

Ansoff, I. (1957), 'Strategies for Diversification', Harvard Business Review, September-October, 113-124.

Araujo, L., Dubois, A. and Gadde, L.E. (2003), 'The multiple boundaries of the firms', Journal of Management Studies, Vol. 40 No. 5, pp. 1255-77.

Axelsson, B. (1992), Corporate Strategy Models and Networks - Diverging Perspectives. In B. Axelsson and G. Easton (eds.), Industrial Networks: a New View of Reality, Routledge, pp. 184-204.

Castells, M. (1996), The Information Age: Economy, Society and Culture. Volume 1. The Rise of the Network Society. Oxford, Blackwell.

Ford, D. and Håkansson H. (2006), 'IMP: Some Things Done, Much More to Do', European Journal of Marketing, Vol. 40, No. 3-4, pp. 248-258.

Ford, D. Gadde LE, Håkansson, H. Snehota, I. (2003), Managing Business Relationships, 2nd edition, Chichester, John Wiley.

Ford, D., Håkansson, H. and Johanson, J. (1986), 'How Do Companies Interact?' Industrial Marketing and Purchasing, Vol. 1, No. 1, 26-41.

Gadde, L.E.; Huemer, L. and Håkansson H. (2003), 'Strategizing in Industrial Networks', Industrial Marketing Management, Vol. 32, No. 5, pp. 357-365.

Gaertner, G.H. and Ramnarayan, S. (1993), 'Organizational effectiveness: an alternative perspective', Academy of Management Review, Vol. 8, No. 1, pp. 97-107.

Gnyawali, D. R. and Madhavan, R. (2001), 'Cooperative Networks and Competitive Dynamics: Structural Embeddedness Perspective', Academy of Management Review, Vol. 26, No. 3, pp. 431-445. 
Grant, R.M. (2002), Contemporary Strategy Analysis: Concepts, Techniques, Applications, 4th edition, Blackwell, Oxford.

Gulati, R., Nohkia, N. and Zaheer, A. (2000), 'Strategic Networks', Strategic Management Journal, Vol. 21, pp. 203-215.

Håkansson, H. and Ford, D. (2002), 'How should companies interact in business networks?', Journal of Business Research, Vol. 55, No. 2, pp. 133-145.

Håkansson, H. editor, (1982) International Marketing and Purchasing of Industrial Goods: An Interaction Approach, Chichester, John Wiley.

Johanson, J. and Mattsson, L. G., (1992), Network Positions and Strategic Action - An Analytic Framework, in B. Axelsson and G. Easton (Eds.), Industrial Networks: a New View of Reality, Routledge, pp. 204-217.

Kriesberg, L. (1955), Occupational Controls Among Steel Distributors, American Journal of Sociology, November, pp. 203-212.

Lorenzoni, G. and Baden Fuller, C. (1995), 'Creating a Strategic Center to Manage a Web of Partners', California Management Review, Vol. 37, No. 3, pp. 146-162.

Lorenzoni, G. and Lipparini, A., (1999), 'The leveraging of inter-firm relationships as a distinctive organizational capability: a longitudinal study', Strategic Management Journal, Vol. 20, pp. 317-318.

Loughlin, M. (2005), 'Constitutional Theory: A 25th Anniversary Essay', Oxford Journal of Legal Studies, Vol. 25, pp. 183-202.

Luehman, T. A., (1998), 'Strategy as a Portfolio of Real Options', Harvard Business Review, SeptemberOctober, pp. 89-99.

Madhavan R., Koka B.R and Prescott J.E. (1998), 'Networks in Transition: How Industry Events (Re) Shape Interfirm Relationships', Strategic Management Journal, Vol. 19, No 5, May, pp. 439-59.
Malmberg, A. and Maskell, P. (2002), 'The elusive concept of localization economies: towards a knowledge-based theory of spatial clustering', Environment Planning, Vol. 34, pp. 429-449.

Mintzberg, H. (1979), 'An emerging strategy of 'direct' research', Administrative Science Quarterly, Vol. 24, pp. 582-9.

Mintzberg, H. and Waters, J.A. (1985), 'Of strategies, deliberate and emergent', Strategic Management Journal, Vol. 6, No. 3, pp. 257-72.

Moran, P., Ghoshal, S. (1999). 'Markets, firms and the process of economic development', Academy of Management Review, Vol. 24, No. 3, pp. 390-412.

Mouzas, S. (2006a), 'Marketing Action in Networks', European Journal of Marketing, Vol. 40, No. 11-12, pp. 1271-1291

Mouzas, S. (2006b), 'Efficiency versus Effectiveness in Business Networks', Journal of Business Research, Vol. 59, pp. 1124-1132

Pettigrew, A.M. and Whittington, R. (2002), 'Strategic management: the strengths and limitations of a field', in Pettigrew, A., Thomas, H. and Whittington, R. (eds.), Handbook of Strategy and Management, Sage, London, pp. 430-44.

Porter, M.E. (1996), 'What is strategy?', Harvard Business Review, Vol. 74, November-December, pp. 61-80.

Porter, M.E. (1998), 'Clusters and the New Economics of Competition’, Harvard Business Review, Nov - Dec, pp. 77-90.

Ritter, T. (2000), 'A framework for analyzing interconnectedness of relationships', Industrial Marketing Management, Vol. 29, No. 4, pp. 317-27.

Ritter, T. and Gemunden, H.G. (2003), 'Interorganizational relationships and networks: an overview', Journal of Business Research, Vol. 56, pp. 691-7. 
Smircich, L. and Stubbart, C. (1985), 'Strategic Management in an Enacted World', Academy of Management Review, Vol. 10, No. 4, pp. 724-738.

Strauss, D A. (1999), 'What is Constitutional Theory?', California Law Review, Vol. 87, No. 3, pp. 581-592.

Zakeer A. and G. B. Bell, (2005), 'Benefiting from Network Position: Firm Capabilities, Structural Holes and Performance', Strategic Management Journal, Vol. 26, pp. 809-825.

Zolkieweski J. and Turnbull P.W. (2002), 'Relationship Portfolios: Past Present and Future', in D Ford (ed.) Understanding Business Marketing and Purchasing, London, Thomson Learning, pp. 289-304.

\section{David Ford}

Affiliate Professor

Euromed

Ecole de Management

BP 921-13288

Marseille

France

33491827800

David.Ford@euromed-management.com

\section{Stefanos Mouzas}

Management School

Lancaster University

Lancaster LA1 4YW

United Kingdom

Tel.: +44 1524593908

S.Mouzas@lancaster.ac.uk 